(C) 1984 ISIJ

高炉出銑樋材のスラグ表面における局部溶損

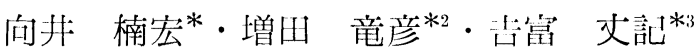

原田 力 ${ }^{* 3} \cdot$ 藤本章一郎 ${ }^{* 3}$

\title{
Local Corrosion of Blast-furnace-trough Material at the Slag Surface
}

\author{
Kusuhiro MukaI, Tatsuhiko Masuda, Jyouki Yoshitomi, \\ Tsutomu Harada, and Shöichiro Fujimoto
}

\begin{abstract}
Synopsis :
Laboratory corrosion test of clay-bonded SiCi specimen at the slag surface has been carried out in argon, argon-oxygen and air, in order to elucidate the mechanism of local attack of blast-furnace-trough material at the slag surface.

The local corrosion arises only in the oxidizing atmosphere in the narrow zone just above the slag surface. The corrosion zone of solidified specimen during the progress of the corrosion is covered with thin liquid slag film. Supplying rate of oxygen from the atmosphere gives remarkable influences on the relations between the corrosion rate and dipping times, slag compositions, etc. It is estimated that the slag film, crept up from the bulk slag, plays important roles in the occurence of the local corrosion by accelerating mass transfer and causing the abrasion of the specimen due to its active movements in diffusion layer caused by Marangoni effect. SiC granules on the surface of the specimen are oxidized by iron oxide in the film into carbon granules, which causes Marangoni effect and also facilitates the dissolution and abrasion of the specimen. Some countermeasures against the local corrosion have been offered from the corrosion mechanism.
\end{abstract}

\section{1. 緒言}

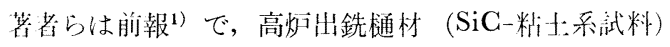
のスラグーィタル界面における局部溶損現象を钼察し,局 蔀溶損には，樋材一メタル間に侵入したスラグフイルム (以後単に SF と即す) のマランジ二効果などによる活 発な動きと, SF に上る铎材表闻の $\mathrm{SiC}$ (炭化理素) の 持続的酸化が重要な役割を果しているものと報售した。 ところで，高炣出銑樋はスラグ表面付近でも局部的に損 耗する ${ }^{2)}$ ・ スラグーメタル界面での樋材の局部溶損が，固 体 $\mathrm{SiO}_{2}$ のスラグ表面での局部溶損 ${ }^{3)}$ 之本質的に同様の

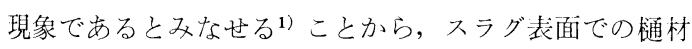
の局部溶損も根本的には同梯の現象之推察される. 本研 究ではそこで，前報1) と同様の実験力法で，SiC-粘土系 を基本とする試料と高炉組成スラグとを用い，スラグ表 面での局部溶損を実験室的に調べ，高炉出銑樋のスラグ 衣面付近にお打る局部的な損耗の機構を明らかにしょら としたものである.

\section{2. 実 験 方 法}

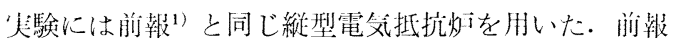
と買なるのは, 空気または $\mathrm{Ar}-\mathrm{O}_{2}$ 混令ガスを試料衣面面 に供給するため, 上部水冷キャップの孔を通して, 反忍 管内に内径 $4 \mathrm{~mm}$ の 2 本のアルミナ管を試料の阔側に 取り付け, 2 本の管の先端(試料の局部溶損部より $3 \mathrm{~cm}$ の距離）からガスを吹きつけたことである。

没漬試料としては, 失際の铎材が主に $\mathrm{SiC}$, 粘土执よ び $\mathrm{Al}_{2} \mathrm{O}_{3}$ から構成されているので, $\mathrm{SiC}$-粘土系試料と $\mathrm{Al}_{2} \mathrm{O}_{3}$ 系試料の 2 種類を用いた。前者は 325 mesh 以卜 の $\mathrm{SiC}$ 粉末に粘土を調合, 金型成形し, $1450^{\circ} \mathrm{C}$ で $2 \mathrm{~h}$ 還元雲囲気中で焼成後, $12 \phi \times 85 \mathrm{~mm}$ の円柱に加工し たもので, Table 1 に組成と物性值を示す. 後者は抄欺 の緻密質アルミナ $\left(99.5 \% \mathrm{Al}_{2} \mathrm{O}_{3}\right)$ で直径 $10 \mathrm{~mm}$ のも のを用いた。

スラグは特級試楽の炭酸カルシウム $(99 \%)$ を知分 解した酸化カルシウム，特級試薬の無水珄酸 ( $99 \%)$, 燁

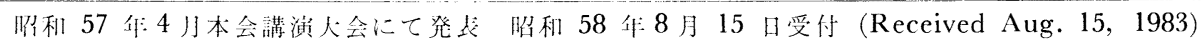

* 九州工業大学 工博 (The Kyushu Institute of Technology, 1-1 Sensui-cho Tobata-ku Kitakyushu 804)

*2 九州工業大学大学院 (現：黑崳篤業(株)) (Graduate School, The Kyushu Institute of Technology, Now Kurosaki Refractories Co., Ltd.)

*3 黑崎密業(株)技術研究所 (Technical Research Laboratory, Kurosaki Refractories Co., Ltd.) 
Table 1. Chemical composition and physical properties of specimen.

\begin{tabular}{cccccc}
\hline \multicolumn{2}{c}{ Chemical composition (wt\%) } & $\begin{array}{c}\text { Apparent } \\
\text { density } \\
\left(\mathrm{g} / \mathrm{cm}^{3}\right)\end{array}$ & $\begin{array}{c}\text { Bulk } \\
\text { density } \\
\left(\mathrm{g} / \mathrm{cm}^{3}\right)\end{array}$ & $\begin{array}{c}\text { Apparent } \\
\text { porosity } \\
(\%)\end{array}$ \\
\hline 67.4 & 21.0 & 11.6 & 3.00 & 2.10 & 29.9 \\
\hline
\end{tabular}

焼アルミナ $(99.5 \%)$ を調合し, 黒鉛るつぼ中, 高周波 誘導炉にて $1600^{\circ} \mathrm{C}$ で $2 \mathrm{~h}$ 溶融し, 急冷, 粉砕したも ので, 高炉スラグ組成に近い, $40.7 \% \mathrm{CaO}, 38.1 \% \mathrm{SiO}_{2}$, $21.2 \% \mathrm{Al}_{2} \mathrm{O}_{3}$ の組成のスラグ（スラグ $\mathrm{A}$ と呼ぶ）を主に 用いた.るつぼは黒鉛と $\mathrm{SiC}$ を粘土結合したもの（内 径 $41 \mathrm{~mm}$, 深さ $52 \mathrm{~mm}$ ) で, $31.5 \% \mathrm{C}, 30.0 \% \mathrm{SiC}$, 残 りは粘土である。

以下の実験手順により引き上げ試料と炉冷試料の 2 種 類を作製し, 前者は溶損形状と溶損量の測定に, 後者は 溶損部のミクロ組織の観察と組成の分析に用いた。引き 上げ試料の場合, 測定温度 (主に $1550^{\circ} \mathrm{C}$ ) 近くで 30 $\min$ 予熱した試料を， $70 \mathrm{~g}$ のスラグ中， $35 \mathrm{~mm}$ の深さ に浸漬し, 所定時間浸漬後引き上げ, $5 \mathrm{~min}$ 回転して付 着スラグの除去に努めた。通銑時の溶損状態を調べる目 的で, 一部の引き上げ試料では, 浸漬中の試料を回転さ せた、浸漬中は 2 本のアルミナ管の先端より, 所定の酸 素含有量のガスを試料に吹き付け, 昇降温はAr 気流中, $360^{\circ} \mathrm{C} / \mathrm{h}$ で行つた. 試料の残存付着スラグは冷却後, $20 \%$ の弗酸水溶液に浸漬して除去し, 工場顕微鏡 (1) $1000 \mathrm{~mm}$ まで読及取り可能)で，試料端から一定の距離 の試料径を 6 力所測定し, 平均值を求めた. 炉冷試料の 場合, 試料の引き上げ操作がない添は, 引き上げ試料 と全く同じ操作である.

スラグの化学分析には酸分解重量法を用いた。後述す る炉冷試料の SF の分析には EPMAを用い, 濃度補正 には, Bence-Albee ${ }^{4)}$ 法を用いた。

\section{3. 結果と考察}

\section{$3 \cdot 1$ 試料の溶損状況}

溶損形状と局部溶損の生起条件 : Photo. 1 に示す種 々の実験条件のもとで得られた引き上げ試料の溶損状態 を整理し，次の結果を得た。

（i） スラグ表面付近でくびれを持つ形の溶損，すな わら明瞭な局部溶損が生起したもの：空気，または $\mathrm{Ar}$ $21 \% \mathrm{O}_{2}$ の酸化性雲团気での $\mathrm{SiC}$-粘土系試料. この場 合, 局部溶損はスラグーメタル界面の有無に関係なく生 起する.

(ii) 局部溶損がほとんど生起しなかつたもの：Ar 雾囲気での SiC-粘土系試料, 酸化性䨌囲気でスラグ表

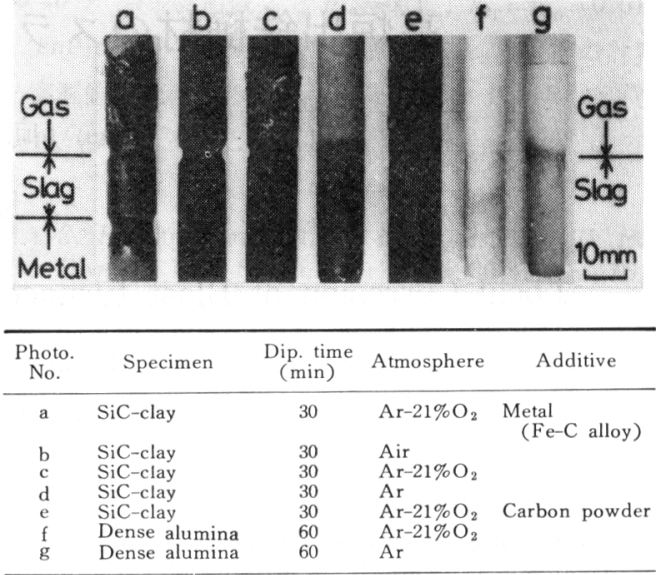

Photo. 1. Wearing profiles of specimens dipped in slag- $\mathrm{A}$ at $1550^{\circ} \mathrm{C}$ in various conditions.

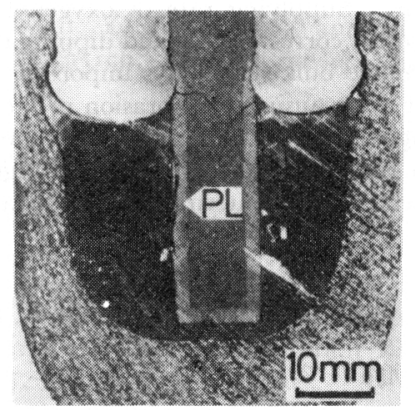

Photo. 2. Vertical section of specimen dipped in slag-A for $30 \mathrm{~min}$ in $\mathrm{O}_{2}$ atmosphere at $1550^{\circ} \mathrm{C}$. PL : Slag penetrated layer.

面を炭素粉で覆つた場合の $\mathrm{SiC}$-粘土系試料, Ar 雾囲気 抢よび酸化性雲囲気での $\mathrm{Al}_{2} \mathrm{O}_{3}$ 系試料. このようにス ラグ表面における $\mathrm{SiC}$-粘土系試料の局部溶損は, 酸化性 雾囲気での夕生じる点で, スラグーメタル界面の場合 ${ }^{1)}$ と 異なる.

以上の結果より， スラグ表面で局部溶損が生じた $\mathrm{SiC}$ 一粘土系試料に着目し，以後の実験は，この試料と溶融 スラグ， Ar - $\mathrm{O}_{2}$ 混合ガス雾囲気の組み合わせで行つた。

局部溶損の状態：局部溶損の位置は, Photo. 2 の炉冷 試料に示すように, スラグ相本体表面（以後スラグ表面 と呼ぶ）より上部にあり, 空気 $(400 \mathrm{ml} / \mathrm{min}), \mathrm{Ar}-21 \%$ $\mathrm{O}_{2}(400 \mathrm{ml} / \mathrm{min})$ の場合でも同様である.ささらに, 浸漬 実験終了直前に, 前述のアルミナ製ガス導入管を降下さ せ，下端がスラグ表面に接触した（ガスが流れなくなる） 位置を測定することにより，試料浸漬中も局部溶損部の 下端は，スラグ表面より上にあることがわかつた。

スラグフイルムの存在 : Photo. 3 に示す局部溶 損部 


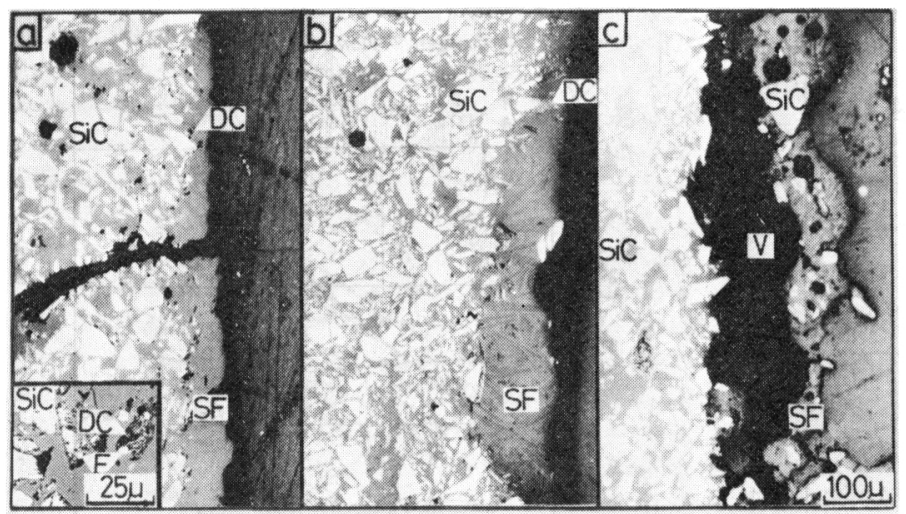

Photo. 3. Microstructures of slag film creeping up along the surface of the specimen dipped in slag- $\mathrm{A}$ at $1550^{\circ} \mathrm{C}$ for $30 \mathrm{~min}$ in the atmospheres, (a) : $\mathrm{Ar}$ $\left(99.998 \%\right.$ over), (b) : $\mathrm{Ar}-21 \% \mathrm{O}_{2}$ gas mixture and (c) : $100 \% \mathrm{O}_{2}$. $\mathrm{SiC}: \mathrm{Sili}-$ con carbide. SF : Slag film. DG : Dissociated carbon from SiC. V : Void.

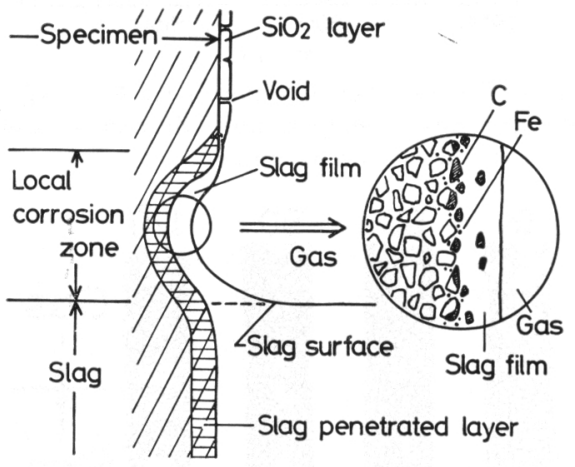

Fig. 1. Sketches of the local corrosion zone and the microstructure.

のミクロ組織から明らかなよらに，局部溶損部は，下方 のスラグ相本体から連続して続く, 90〜120 $\mu \mathrm{m}$ の $\mathrm{SF}$ で覆われ，これはスラグの浸透層 (Photo. 2 の PL) の 上端まで続く. Fig. 1 にその概略図を示す. この SF は Ar 雾囲気の炉冷試料にも同様に存在する (Photo. $3)$.

\section{$3 \cdot 2$ 局部溶損におよぼす諸因子の影響}

局部溶損の程度を示す值として, 最大局部溶損位置で のくぽみの相対量 $\Delta d_{\mathrm{s}-\mathrm{g}}(\%)=\left(d_{0}-d_{\mathrm{s}-\mathrm{g}}\right) / d_{0} \times 100$ (こ の量は実用的には，樋の寿命に関係する重要な值であ る）を用い，溶損量， $\Delta d_{\mathrm{s}-\mathrm{g}}(\%)$ におよぼす諸因子の影 響を調べた。 $d_{0}$ は試料の原直径， $d_{\mathrm{s}-\mathrm{g}}$ は最大局部溶損 位置での試料径.

\section{$3 \cdot 2 \cdot 1$ 気相中の酸素}

$1550^{\circ} \mathrm{C}$, 浸漬時間 $30 \mathrm{~min}$ で, $\mathrm{Ar}-\mathrm{O}_{2}$ 混合ガス中の 酸素含有量と混合ガス流量を変化させた結果を Fig. 2 に示す，空気と同じ $21 \% \mathrm{O}_{2}$ の場合，流量の増加ととも に溶損量が増加乙, 酸素の供給速度が溶損速度に支配的 な影響を扎よぼす。 $50 \% \mathrm{O}_{2}$ の場合， $800 \mathrm{ml} / \mathrm{min}$ の流量 までは $21 \% \mathrm{O}_{2}$ の場合と同様であるが，艺れ以上の流量

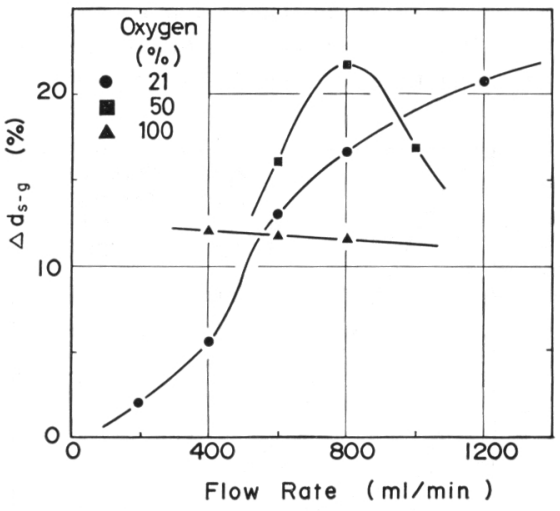

Fig. 2. Relation between the linear loss, $\Delta d_{\mathrm{s}-\mathrm{g}}$ and flow rate of $\mathrm{Ar}-\mathrm{O}_{2}$ gas mixture. Specimen was dipped in slag-A for $30 \mathrm{~min}$ at $1550^{\circ} \mathrm{C}$.

では溶損量が減少しはじめ, 溶損速度に対して他の過程 の抵抗が大きくなることを示す． $100 \% \mathrm{O}_{2}$ では，溶損量 は流量にほとんど依存せず，しかる $50 \% \mathrm{O}_{2}$ の場合より 低い。この結果は, 他の過程が溶損速度に支配的な影響 を与㝋ていことを示す。

\section{$3 \cdot 2 \cdot 2$ 浸漬時間}

浸漬時間 $30 \mathrm{~min}$ のもとで明らかになつた Fig. 2 の 結果から次の 3 つの典型的条件を選び, 溶損量の時間变 化を調べた. その結果を Fig. 3 に示す.

（1）気相中の酸素の供給過程が溶損速度に支配的影 響を与える条件として，21\% $\mathrm{O}_{2}, \mathrm{Ar}-\mathrm{O}_{2}$ 流量 $400 \mathrm{ml} /$ $\min$.

（2）（1）以外の他の過程の影響が大となる分岐点と して, $50 \% \mathrm{O}_{2}, \mathrm{Ar}-\mathrm{O}_{2}$ 流量 $800 \mathrm{ml} / \mathrm{min}$.

（3）（1）以外の他の過程の影響が支配的な条件とし $\tau, 100 \% \mathrm{O}_{2}, \mathrm{O}_{2}$ 流量 $600 \mathrm{ml} / \mathrm{min}$.

(1)では, 溶損量は時間の経過とともに全体として増 加するが，階段状の増加を示す.（2)と（3)では, 溶損 


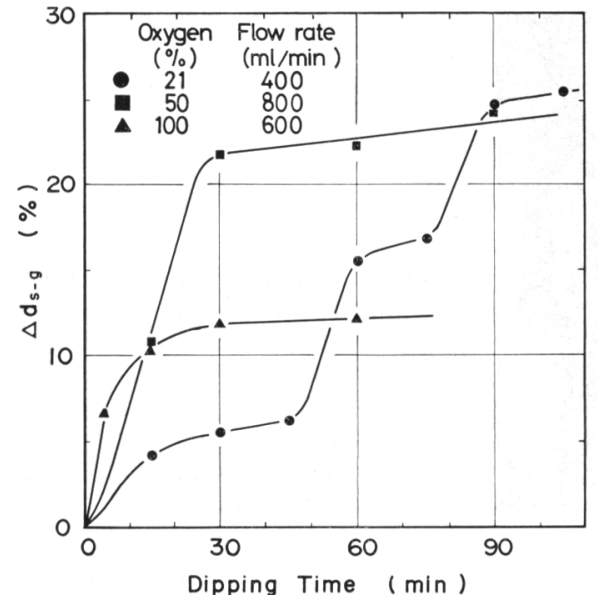

Fig. 3. Relation between the linear loss, $\Delta d_{\mathrm{s}-\mathrm{g}}$ and dipping time at $1550^{\circ} \mathrm{C}$ for slag-A.

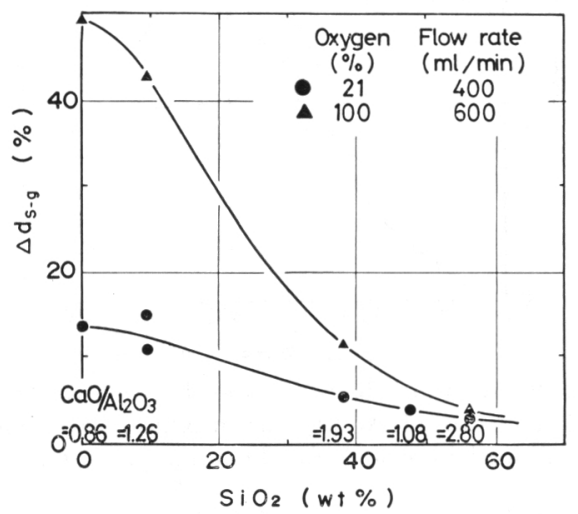

Fig. 4. Effect of $\mathrm{SiO}_{2}$ content in slag on the linear loss, $\Delta d_{\mathrm{s}-\mathrm{g}}$. Specimens were dipped for $30 \mathrm{~min}$ at $1550^{\circ} \mathrm{C}$.

量は最初急激に増加するが，西る時間経過後は溶損速度 が著しく低下する.（3)では，初期の溶損速度が 3 つの 条件の中で最大であり, 溶損速度の減少し始める時期も 最も早い.

$3 \cdot 2 \cdot 3$ スラグ組成

$3 \cdot 2 \cdot 2$ で示した $(1)$ と( 3 )の条件下でスラグ組成を変 化させた結果を Fig. 4 に示す.（3）の条件下では, (1) 亿比べて, 溶損量はスラグ中の $\mathrm{SiO}_{2}$ 濃度の減少と ともに著しく増加し， $\mathrm{SiO}_{2}$ 濃度が溶損速度に大きな影 響を拉よ㳯す。

\section{$3 \cdot 2 \cdot 4$ 温度}

$3 \cdot 2 \cdot 3$ と同様に ( 1 ) と ( 3 )の条件下で，溶損量に打上 ぼす温度の影響を調べた。そ結果を Fig. 5 と示す。 (1) では温度の上昇とともに溶損量はわずかに低下する

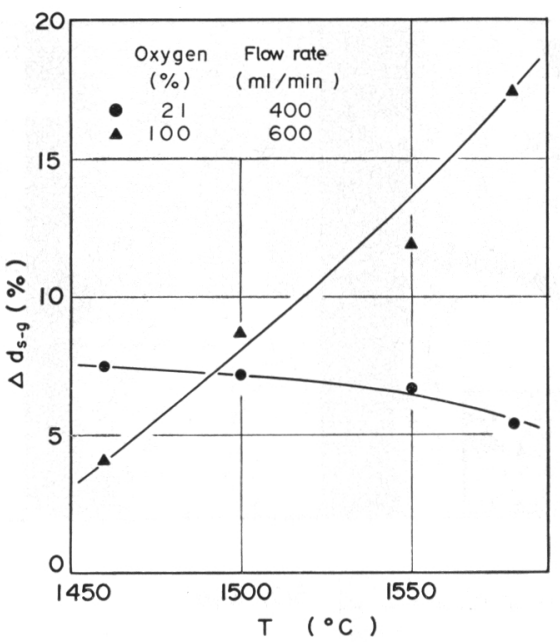

Fig. 5. Relation between the linear loss, $\Delta d_{\mathrm{s}^{-\mathrm{g}}}$ and experimental temperature. Specimens were dipped in slag-A for $30 \mathrm{~min}$.

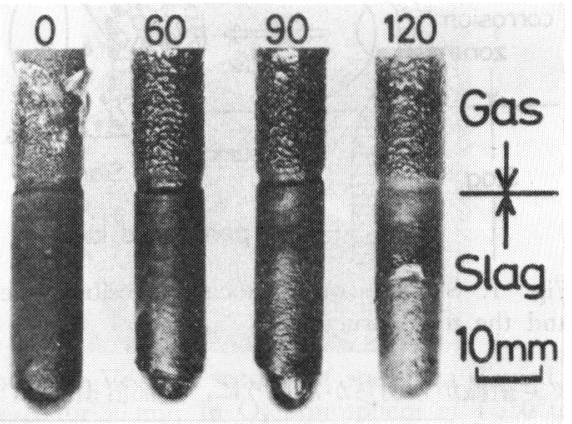

Photo. 4. Wearing profiles of specimens after rotational dissolution test in slag-A. Numbers on top indicats the number of revolution in $\mathrm{rpm}$.

が, (3)では, 温度の上昇とともに溶損量は直線的に増 加与る.

\section{$3 \cdot 2 \cdot 5$ 試料の回転}

$3 \cdot 2 \cdot 2$ 亿示した $(1),(3)$ の雾囲気下, 試料の回転数 $120 \mathrm{rpm}$ (実用樋での溶銑, スラグの樋に対する相対 速度に拈拈上そ等しい）以下の範囲に拈いては，溶損量， $\Delta d_{\mathrm{s}-\mathrm{g}}(\%)$ は回転数の増加と之もに, 最初静止浴に比べ

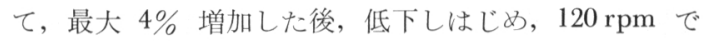
は再び静止浴中での值に近くなつた．Photo. 4 に(1)の 場合の溶損状況を示す. $120 \mathrm{rpm}$ ではスラグ表面だけで なく，スラグ相本体中でも試料の溶損が顕著になる。

\section{$3 \cdot \mathbf{3}$ スラグの挙動}

$3 \cdot 3 \cdot 1$ スラグフイルムのミクロ組織と組成

次の 3 つの条件に打ける局部溶損部のミク口組織を Photo. 3 に, EPMA による SF の分析結果を Fig. 6 示吉. 


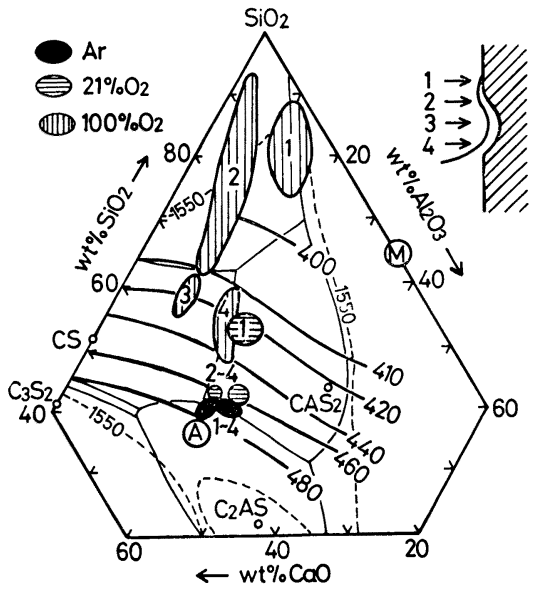

Fig. 6. Chemical composition of slag film in the local corrosion zone of the specimen dipped in slag-A for $30 \mathrm{~min}$ at $1550^{\circ} \mathrm{C}$ and line of constant surface tension (in dyn $/ \mathrm{cm}$ ) at $1600^{\circ} \mathrm{C}^{5}$ ).

（1）局部溶損が牛起しない条件（Ar 雾围気）：

Photo. 3a に示すように, SF はほぼ均一な組織で, 試料 との境界には $\mathrm{SiC}$ 䊀が並び，その $\mathrm{SiC}$ 䊀は削趣1) と同 様, 部分的に黑炏色に変質し, その付近に $\mathrm{Fe}$ 粘が存在 する・スラグ相本体の組成 (Fig. 6 の中のA) と SF の $\mathrm{SiO}_{2}$ 濃度の差は $5 \%$ 以内にある。この結果より, $\mathrm{SF}$ と試料との閒には, 溶解反応などの相 $斤$ 作用が少ないこ とがわかる。

(2) 局部溶損が進行する条件 $\left(\mathrm{Ar}-21 \% \mathrm{O}_{2}\right)$ : Photo. $3 \mathrm{~b}$ に示すよらに, SF にささの葉状の不均一な組 織が 認められ，試料と $\mathrm{SF}$ 境界の $\mathrm{SiC}$ 粒の変質が, $(1)$ の 場合より顕著で，主に SF に接する側が部分的に変質 し, 細い黑灰色の帯を形づくる. 変質した $\mathrm{SiC}$ の一部 は，（1）の場合と異なり $\mathrm{SF}$ 中に懸濁し，SF一気相界面 にまで達するものもある，SF 表面で父相と接する $\mathrm{SiC}$ には変質部は見当たらない. SF の組成はスラグ相本体 の組成より $4 \sim 13 \%$ 程度 $\mathrm{SiO}_{2}$ 濃度が高く (Fig. 6), 組成の変化は, $\mathrm{SiO}_{2}$ コーナーと試料のマトリックスで

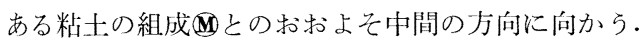

(3) 局部溶損が停滞する条件 $\left(100 \% \mathrm{O}_{2}\right.$ 雾用気)： Photo. 3c に示すように, SF と試料の境界が剝離した り, 不規則な形の多数の空陌が存在する. $\mathrm{SiC}$ 粒の変質 は少なく, $\mathrm{SiC}$ 粒のまま $\mathrm{SF}$ 中に多数賏濁し, その付近 には㑇状の不均一な組織が存在する.SF の組成は, $\mathrm{SiO}_{2}$ コーナーー向かつて $\mathrm{SiO}_{2}$ 濃度が大幅に增加し, 浸漬実験温度の $1550^{\circ} \mathrm{C}$ では固相の部分も西る。この ように，局部溶損が著しく停滞する条件では，SF の $\mathrm{SiO}_{2}$ 莀度は非常に高く, その $\mathrm{SF}$ に包まれるようにし

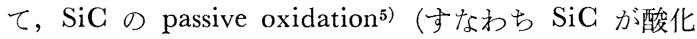
されて $\mathrm{SiO}_{2}$ となり $\mathrm{CO}, \mathrm{CO}_{2}$ ガスを発生) が生じる.

\section{$3 \cdot 3 \cdot 2$ スラグ相本体の組成}

Fig. 3 で，溶損速度が，(a)大きい場命 $\left(100 \% \mathrm{O}_{2}\right.$, $600 \mathrm{ml} / \mathrm{min}, 5 \mathrm{~min}$ 浸漬) と(b) 汪とんど零に近い場命 $\left(100 \% \mathrm{O}_{2}, 600 \mathrm{ml} / \mathrm{min}, 30 \mathrm{~min}\right.$ 浸漬) でのスラグ相本体 の上下方向の $\mathrm{SiO}_{2}$ 濃度を凝固後のスラグを分析して調 べた．（a）では上下方向の $\mathrm{SiO}_{2}$ 濃度の相違は $1 \%$ 以 内であるが，（b )ではスラグ表面部の方がスラグ相本体 中より $3 \%$ 高い。气れゆえ局部溶損が停滞する時期に は，スラグは溶出した $\mathrm{SiO}_{2}$ (試料および Photo. 2 に示 するつぼの局部溶損からも）で富化され粘性が高い。 3.3 .1 の ( 3 )の結果との対応より, その時期には SF も $\mathrm{SiO}_{2}$ で富化されており, 局部溶損部の $\mathrm{SF}$ とスラグ衣 面は動きにくい状態にある。

\subsubsection{SiC-スラグフイルム間の反応}

Photo. 3 に示した SF-試料の境界付近に多い $\mathrm{SiC}$ 档。 の変質は, 前報1)で述べたように，スラグ中の酸素によ b $\mathrm{SiC}$ が $\mathrm{SiO}_{2}$ と炭素（この炭素を分解 $\mathrm{C}$ と呼ぶ）に なり, $\mathrm{SiO}_{2}$ は $\mathrm{SF}$ 中に溶解し, 分解 $\mathrm{C}$ はとの $\mathrm{SiC}$ 粆 に近い形のまま懸濁したものと考光ることができる.

酸化性雲囲気では, 酸素分圧が高く, 合成スラグ, 試 料の粘土中には酸化鉄がそれぞれ $0.1 \mathrm{wt} \%$ (実験後の分 析結果, wt \% は全酸化鉄を $\mathrm{FeO}$ として換算), $0.9 \mathrm{wt}$ $\%$ 含まれるので, 雀部ら ${ }^{6)}$ の結果に従光ば, $\mathrm{O}_{2}(\mathrm{~g})$ は $\mathrm{SF}$ 中に化学溶解しこの時生じた $\mathrm{O}^{2-}$ と positive hole が $\mathrm{SiC}$ 粒表面へ供給されると考元られる。その結果, 次の反応 $(1),(2)$ につて, $\mathrm{SiC}$ 粒の酸化が持続的に 進むものと考学られるた。

$$
\begin{aligned}
& \mathrm{SiC}+2\left(\mathrm{Fe}_{2} \mathrm{O}_{3}\right)=\left(\mathrm{SiO}_{2}\right)+4(\mathrm{FeO})+\mathrm{C}(\mathrm{S}) \cdots(1) \\
& 2(\mathrm{FeO})+1 / 2 \mathrm{O}_{2}(\mathrm{~g})=\left(\mathrm{Fe}_{2} \mathrm{O}_{3}\right) \cdots \cdots \cdots \cdots \cdots \cdots(2)
\end{aligned}
$$

熱力学的数值 ${ }^{177}$ を用いた反応 (1)，(2) の平衡位湜 の計算結果からも, $P_{\mathrm{O}_{2}} \geqq 0.21 \mathrm{~atm}$ で反応 $(1)$ は右へ進 又得る.

$3 \cdot 3 \cdot 4$ 局部溶損部でのスラグフイルムの運動

局部溶損部において，本系で生じるマランゴニ効果に 基づく $\mathrm{SF}$ の流速を LUDVIKsson と LigHTFOOT ${ }^{8)}$ の解 析を用いて算出した。すなわち，垂直方向（Z軸）に牴 面張力公配 $\alpha\left(\mathrm{dyn} / \mathrm{cm}^{2}\right)$ のある液膜が垂淔平板に汴り て, 定常状態玨流で流れるときのZ 軸方向の流速 $V_{\mathrm{Z}}$ は,

$$
V_{\mathrm{Z}}=1 / \mu \cdot(\partial p / \partial z+\rho g)\left(1 / 2 \cdot y^{2}-h y\right)+\alpha y / \mu \cdots(3)
$$

したがつて, 液膜表面, $y=h\left(\right.$ 液膜厚さ)での流速 $V_{z \cdot h_{1}}$ は

†な㧍，分解 $\mathrm{C} の$ 内(武料)側には微少な Fe 粒が認められることから， スラグーメタル界面での局部溶䭫の場合 ${ }^{1)}$ と同様の反応, $\mathrm{SiC}+2(\mathrm{Fe}$ O) - $\left(\mathrm{SiO}_{2}\right)+\mathrm{C}+2 \mathrm{Fe}$ の生起も考光られる. しかし, $\mathrm{Fe}$ 粒の量はス ラグーメタル界面の場合よりも著しく少ない。 


$$
V_{\mathrm{z} \cdot \mathrm{h}}=-h^{2} / 2 \mu \cdot(\partial p / \partial z+\rho g)+\alpha y / \mu
$$

ここで, $\mu$ は粘性係数 $(\mathrm{g} / \mathrm{cm} \cdot \mathrm{s}), p$ は液膜内の圧力 $\left(\mathrm{dyn} / \mathrm{cm}^{2}\right), \rho$ は液膜の密度 $\left(\mathrm{g} / \mathrm{cm}^{3}\right), g$ は重力加速度 $\left(\mathrm{cm} / \mathrm{s}^{2}\right)$ である. 局部溶損部内では $\mathrm{SF}$ 表面の曲率半径 がZ軸方向に大きく変化していない (Photo. 2) ので, 近似的に $\partial p / \partial z \ll \rho g$ とする. (a ) $\mathrm{Ar}-21 \% \mathrm{O}_{2}$ で溶損 進行中の場合 $V_{\mathrm{z} \cdot \mathrm{h}}=-0.13 \mathrm{~cm} / \mathrm{s} ，$ （b ） $100 \% \mathrm{O}_{2}$ の溶損 停滞期の場合, $V_{\mathrm{z} \cdot \mathrm{h}}=-0.017 \mathrm{~cm} / \mathrm{s}$ となる. 計算には Fig. 6 の SF 組成より, (a )では $\mu=9.2 \mathrm{~g} / \mathrm{cm} \cdot \mathrm{s}^{9)}, \rho_{\mathrm{S}}$ $=2.59 \mathrm{~g} / \mathrm{cm}^{3}{ }^{10)}, \alpha=-25 / 0.2 \mathrm{dyn} / \mathrm{cm}^{2}{ }^{11)}, h=0.009 \mathrm{~cm}$ (Photo. 3), (b) では $\left.\mu=150 \mathrm{~g} / \mathrm{cm} \cdot \mathrm{s}^{9}\right), \rho_{\mathrm{S}}=2.54 \mathrm{~g} / \mathrm{cm}^{3}$ 10), $\alpha=-40 / 0.2 \mathrm{dyn} / \mathrm{cm}^{211)}, h=0.012 \mathrm{~cm}$ (Photo. 3$) を$ 用いた。

平板と平行な層流を考光, 平板から $h$ の距離 (SF 厚 さと同じ距離) での流速を $V_{\mathrm{z} \cdot \mathrm{h}}$ とする. $h$ が層流境界 内にあり, 平板先端からの距離を $1 \mathrm{~cm}$ （局部溶損部の 上下幅）とした場合，平板から十分に離れた距離での速 度 $V_{\infty}$ は, BLASIUs ${ }^{12)}$ の境界層の解析結果を用いれば， (a ) で $11.3 \mathrm{~cm} / \mathrm{s}$ ，(b) で $6.1 \mathrm{~cm} / \mathrm{s}$ となる. すなわち, 本系でマランゴニ効果に基づく $\mathrm{SF}$ の運動は，平板と平 行な流れの $V_{\infty}$ としては (a) で $11 \mathrm{~cm} / \mathrm{s}$ ，(b) で $6 \mathrm{~cm} /$ $\mathrm{s}$ 程度の値に 相当する. $V_{\infty}$ を $12 \mathrm{~mm}^{\phi}$ の試料棒の周 速度とみなして回転数に換算すると（a），（b )の場合そ れぞれ，180 rpm，100 rpm となる. スラグ相本体での 溶損は静止浴中ではほとんど生じず，120 rpm 以上の回 転を与えると明確な溶損が生じる (Photo. 4) ことから， (a)に执いて，マランゴ二効果による SF の覺乱作用 は，試料の溶損を促進するのに十分の大きさであると推

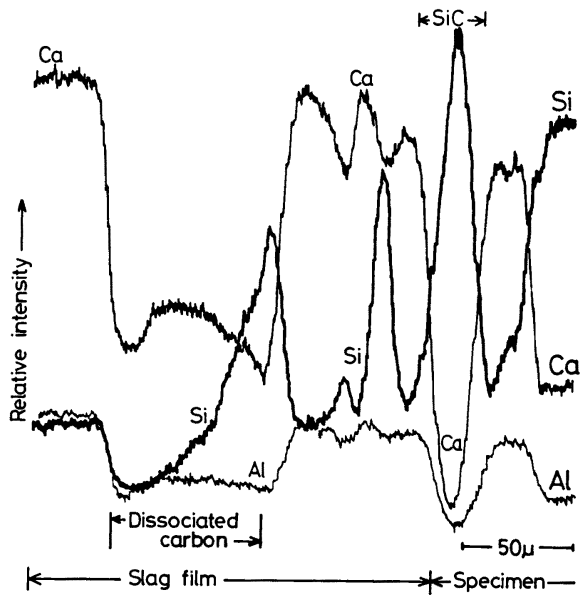

Fig. 7. EPMA line analysis on the slag film in the local corrosion zone of the specimen dipped in slag- $\mathrm{A}$ for $30 \mathrm{~min}$ at $1550^{\circ} \mathrm{C}$ in $\mathrm{Ar}-21 \% \mathrm{O}_{2}$ gas mixture $(400 \mathrm{ml} / \mathrm{min})$.
Table 2. Comparison of observed wearing rates with those calculated by using permeability of oxygen gas in slag.

\begin{tabular}{lccc}
\hline$P_{\mathrm{O}_{2}}$ & Dip. time $(\mathrm{min})$ & \multicolumn{2}{c}{ Wearing rate $\left(\mathrm{g} / \mathrm{cm}^{2} \cdot \mathrm{min}\right)$} \\
\cline { 3 - 4 } & & Calculated & Observed \\
\hline 0.21 & 15 & 0.012 & 0.003 \\
0.5 & 15 & 0.026 & 0.009 \\
1.0 & 5 & 0.043 & 0.016 \\
\hline
\end{tabular}

定できる. しかも Fig. 7 に示すように SF の厚さ方向 には，濃度勾配が認められることから，この SF の運動 は桩散層内にあつて，物質移動をより効果的に促進する と考えられる。

\section{4 溶損におよぼす諸因子の影響の解釈}

気相からの酸素の供給速度との関係 : 局部溶損の停滞 現象が現れるまでの溶損速度は, 酸素の供給速度ととも に増大する (Fig． 3)．そこで SF を通しての酸素の供 給速度が律速と考光, 雀部ら ${ }^{6)}$ の酸素の透過度を用いて 初期の局部溶損速度を計算した。ただし， $\mathrm{SiC}$ 粒が酸化 されただけ試料の溶損が進むとし，フイルム厚さを観察 結果より $90 \sim 120 \mu \mathrm{m}$ とした. 結果を Table 2 に示 す. 実測值とは桁数がおおよそ一致し, しかも $21 \% \mathrm{O}_{2}$ より $50 \% \mathrm{O}_{2}, 100 \% \mathrm{O}_{2}$ になるに従つて一致の程度が良 い.これは, 主に酸素の供給速度が速くなるに従い, 局 部溶損部表面に到達する混合ガスの組成が調合組成に近 くなるためと考えられる.なお， $100 \% \mathrm{O}_{2}$ の酸素供給速 度は，透過度が酸化鉄濃度にほぼ比例する6)ことから， $21 \% \mathrm{O}_{2}$ での酸化鉄 $0.5 \mathrm{wt} \%$ に相当し, 実用高炉スラグ 組成での供給速度に相当する†2.

酸素供給速度大の 場合の局部溶損の停滞現象 (Fig. 3) : 局部溶損部から流れ降りた $\mathrm{SiO}_{2}$ 富化スラグは, 密 度が小さいのでスラグ表面を覆い，拡散などにより，次 第に下部のスラグ相中へと移行する. しかし，局部溶損 速度が大きいと，流れ降りる $\mathrm{SiO}_{2}$ 富化スラグによる $\mathrm{SiO}_{2}$ の供給速度の方が大きくなる結果，スラグ 表面の $\mathrm{SiO}_{2}$ 濃度はさらに增大し, 粘性は高くなり, 表面張力差 が減少し，マランゴニ効果によるスラグの動きは減少す る.そのため物質移動速度は減少し, 局部溶損が停滞す る. $\mathrm{Ar}-21 \% \mathrm{O}_{2}$ では, $\mathrm{SiO}_{2}$ 富化スラグの供給速度が大 きくはないので, スラグ表面の $\mathrm{SiO}_{2}$ が下部スラグ相に 拡散し, 表面の $\mathrm{SiO}_{2}$ 濃度が小さくなると再び表面の動

$\dagger^{2}$ スラグ中の酸素の透過度が微量の酸化鉄に著しく依存する6)てとか ら上觖条件下, 低酸化鉄濃度域での酸化鉄濃度々溶損量との関係に 興味が持たれる.しかし，本実験では，るつぼと試料の粘土中の酸 化鉄の混入はさけ難い，また，SiC-C 系るつぼは，容器によるス ラグの污染と酸素ガスによる容器の損傷防止が可能な容器として必 須のものであるが，高酸化鉄濃度のスラグが使用できない，てのよ うな技術上の問題のため, 酸化鉄濃度の影響の検討は難しく, 今後 の問題々して残される。 
きが活発になり，局部溶損が進行し始める。このプロセ スがくり返し行われる結果, 階段状の局部溶損曲線

(Fig. 3) が現れるものと考えられる.

スラグ組成との関係：酸素の供給速度が増大し，局部 溶損速度が大きくなつても，スラグ相本体の $\mathrm{SiO}_{2}$ 濃度 が低い場合は，粘性の低い組成範囲が広いので，停滞は 生じにくく, 全浸漬時間の平均の溶損速度は増大する.

温度との関係：酸素の供給が不十分な条件 (Fig. 5 の○印）では，温度の上昇とともに，るつぼの酸化など に消費される酸素の割合が多くなり，溶損部への酸素の 供給不足の程度が大きくなる結果, 溶損量が減少し, 酸 素の供給が十分な状態 (Fig. 5 の $\Delta$ 印)では, 温度の上 昇とともにスラグの粘性係数が減少し，拡散係数が増大 することにより，溶解成分のスラグ相本体への移行など が促進されるため溶損量が増加すると推定される.

炭素粉を浮かべた場合：供給される酸素が炭素粉の然 焼に消費される結果, 局部溶損が防止される.

試料回転数との関係：低回転数域では，回転により界 面攪乱およびスラグ相本体の $\mathrm{SiO}_{2}$ 濃度の均一化が助長 されるが, $120 \mathrm{rpm}$ 近くの高回転数域では, 回転により スラグのはい上がりが妨害されるものと推定される．実 際, 高回転数域では, 最大局部溶損部が下方に移る.

\section{5 局部溶損機構の推定}

以上の結果をもとに本系の局部溶損機構を次のように 推定した。濡れによる試料表面へのスラグのはい上がり と, その際生じる SF がマランゴニ効果などで拡散層内 で活発に動くことによつて, 試料組織の流出と物質移動 が促進され，局部溶損部での溶損が進む. マランゴ二効 果の生因は，スラグーメタル界面の場合1)とは異なり，主 に反応 (1)，（2）に伴う $\mathrm{SiC}$ の酸化によつて $\mathrm{SF}$ 中の $\mathrm{SiO}_{2}$ 濃度がスラグ表面より高くなることにある. 一方, 上記 $\mathrm{SiC}$ の酸化は, スラグーメタル界面の場合1) と同様, 試料組織の流出を容易にする．スラグのはい上がり先端 より上では, 試料表面の $\mathrm{SiC}$ が酸素ガスで直接に酸化 され, 高 $\mathrm{SiO}_{2}$ 濃度の融点の高い款を形成し, $\mathrm{SiC}$ の酸 化反応の進行を抑える、スラグ相本体部では, 気相から の酸素の供給が遅く反応 (1)，（2)が停滞することと， 試料一スラグ界面付近のスラグの動きが弱いことのため, 溶損が抑制される。本実験条件下での局部溶損速度の律 速段階は, 試料浸漬の初期では, 気相から試料表面への 酸素の供給過程にあり，時間の経過とともに律速段階 は, 溶損に伴つてスラグ表面に蓄積される $\mathrm{SiO}_{2}$ 成分の スラグ相本体中への移行過程に移る.

以上のように推定した機構をより具体的な形で明らか にするためには，SF のはい上がりと下降の具体的プロ

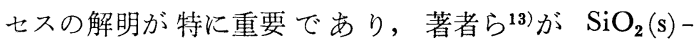
$\left(\mathrm{PbO}-\mathrm{SiO}_{2}\right)$ スラグ系で行つたような $\mathrm{SF}$ の運動の直接 観察と乞の解析が必要であろら.

\section{6 高炉出銑樋の対策}

$3 \cdot 6 \cdot 1$ 高炉出銑樋のスラグ表面における溶損の解釈 実用樋材は, $\mathrm{SiC}$ 粒, 粘土, $\mathrm{Al}_{2} \mathrm{O}_{3}$ (骨材) より成る がこれまでの実験結果より，実用樋の局部溶損も基本的 には SiC-粘土系試料の局部溶損之同様であると推定で きる。しかし, 前報1)で示したよらに, 実際の桶での局部 溶損の幅（上下方向）は，本実験で得られるものよりは るかに大きい，実際の樋では，堰の損耗により貯銑レベ ルがしだいに下降し，通銑時には，貯銑時よりもスラグ 表面の位置が上昇したり，波打つなどして，表面の位置 は，各時期によつてかなりの幅で上下動する.Fig. 8 に

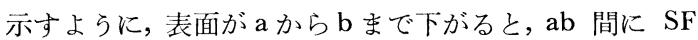
ができ，空気中の酸素によつて，SF を通して $\mathrm{SiC}$ が酸 化され，マランゴ二効果などによる SF の動きにより， $\mathrm{SF}$ 中に懸濁し溶損が始まる。上部で温度が低下した場 合，その部分はそのままの状態で㠜固する，下部は $\mathrm{SiC}$ を懸濁した SF がスラグ表面に流れ込み局部溶損が進 む.一方，スラグ表面が再び上昇すれば，上記の凝固フ イルムは再溶融し，上昇するスラグの動きなどによつて 洗い流される、このようなプロセスのくり返しによつて 溶損が進むものと推定される. 実際，スラグ表面付近の 稼動面には，分解 $\mathrm{C}$ それが懸濁し始めるようすがしば しば見らけられる。またスラグ表面におけける局部溶損の 幅とスラグ表面位置の変化（上下動など）の幅もお扎よ そ一致する. 表面の上下動に伴う加熱, 冷却によつて, スポーリングが生起する可能性も否定はできない。しか し, 実際の觱の切断面観察などからは，その可能性は薄 くまた明らかにスポーリングによる損耗と判断される 場合には，損耗速度が著しく大きく，局部的な溶損は現

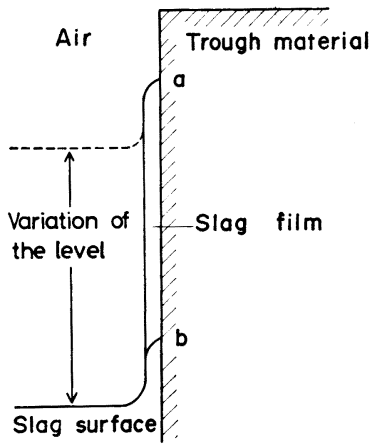

Fig. 8. Formation of slag film due to the variation of slag level in the practical use. 
れず稼動面はほぼ平坦になる。

$3 \cdot 6 \cdot 2$ 局部溶損の防止対策

以上の結果より，実施可能な局部溶損の防止対策とし て，主に二つの方向が考兄られる。一つは，本実験で用 いたよらな試料のマトリックス（粘土）に $\mathrm{Al}_{2} \mathrm{O}_{3}$ を富 化し，高融点化させる方向である.あるいは，上り漳化 しにくい $\mathrm{ZrO}_{2}$ (ジルコニア) などを添加するなど，生 成する SF の粘性を高く, 酸素の透過度の小さいものに することである，もら一つの方向は，侵入する空気で然 焼されやすく，乙かも厚い層が容易に得られるようなわ ら灰，も及がら，炭素粉などをスラグ表面に浮かべるこ と，あるいは㜕全体をカバーするなどして，空気からの 酸素の侵入を可能な限り断つことである.しかし，

Photo. 4 の回転の結果が示すように，120 rpm になる とスラグ相本体部でも試料の溶損が生じ始める。それゆ 党, 酸素を十分断つても, 樋材とスラグの相対速度があ る程度以上になると溶損が生じるので，一方において， 堅牢な組織の樋材をくふらすることも必要である。

\section{4. 結言}

スラグ表面における高灯出銑樋の局部的な損耗の機構 を明らかにする目的で, $\mathrm{CaO}-\mathrm{Al}_{2} \mathrm{O}_{3}-\mathrm{SiO}_{2}$ 系スラグ琵 面に求ける $\mathrm{SiC}$-粘土系試料の局部溶損見象を $\mathrm{Ar}, \mathrm{Ar}-$ $\mathrm{O}_{2}$ おょび空気中で調べ，次の結果を得た。

（1）局部溶損は，酸化性雾囲気でのみ生じ，溶損位 㯰はスラグ表面より上部にある。炉冷試料の観察によれ ば局部溶損部はスラグフイルムで覆われ，溶損の進行中 は液体状態にあり, 試料表面の $\mathrm{SiC}$ 粒は, 気相から供 給されるフイルム中の酸素によつて酸化され，その一部 または全部が炭素粒となつてフイルム中に懸濁する。

（2）局部溶損量と浸漬時間，スラグ組成，温度との 関係は，酸素の供給速度に著しく影響される、試料の回 転による局部溶損量の変化は小さいが，120 rpm ではス ラグ相本体部でも試料の溶損が顕著になる.

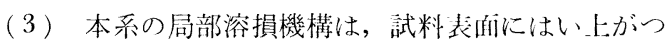

た液体スラグフイルムが，主に $\mathrm{SiC}$ の酸化に伴う $\mathrm{SiO}_{2}$ 濃度の增加のために誘起されたマランゴ二効果によつて 拡散層内で活発に動くことにより, 物質移動を促進し, かつ試料組織の流出を促すとの立場から説明でき，律速 段階は, 試料浸漬初期では, 気相から試料企面への酸素 の供給過程にあり，時間の経過とともにスラグ背面の $\mathrm{SiO}_{2}$ 成分のスラグ相本体けへの移行過程に移ると推定 される.

（4）上記溶損機構をもと飞里用㿹の局部溶損の防止 対策として，スラグフイルムの動きを抑制することと， 気相からの酸素の供給を断つことの 2 つの面から，2，3 の提案を行つた。

\section{交献}

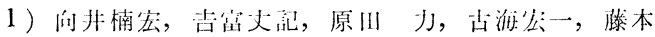
章一郎：鉄と鋼，70 (1984), p. 541

2 ）大庭 宏：渜火物，30 (1978)，p. 45

3 ) 向井楠宏, 岩田章, 原四力, 吉筈丈礼, 滕本 章一郎：日本金属学会誌，47 (1983)，p. 397

4) A. E. Bence and A. L. Albee: J. Geol., 76 (1968), p. 382

5 ) $D . W$. Mckee and $D$. Chatterji: J. $\Lambda \mathrm{m}$. Ceram. Soc., 59 (1976), p. 441

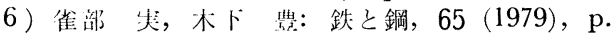
1727

7 ) D. R. Stull and $H$. Prophet: JANAF Thermochemical Tables 2nd ed. (1975) [堀越研究 所]

$8) \quad V$. Ludviksson and E. N. Lightfoot: AlChEJ, 17 (1971), p. 1166

9 ) J.S. MACHIN and T. B. YeE: J. $\Lambda \mathrm{m}$. Ceram. Soc., 31 (1948), p. 200

10）鉄鋼基礎共同研究会溶鋼・溶㳯部会：溶鉄・溶㳯 の物性値便覽，特別報告書 No. 12 (1972) [日 本鉄鋼協会]

11）向井楠厷，不川友美：口本金属学会诘，45(1981), p. 147

12）城㧴 正, 平山 彰, 村上昭浐：移動速度活 (1966), p. 103 [才一公社]

13）向井楠宏，中野哲生，岩田章，大山秀樹，原田 力, 吉富丈距, 藤本章一郎：日本金属学会講演概 装 (1983 年: 10 月), p. 479 